\title{
ISOLATION AND IDENTIFICATION OF A GROWTH INHIBITORY SUBSTANCE FROM HELIOTROPIUM INDICUM L.
}

\author{
Sirinapa Chaipon, ${ }^{1}{ }^{*}$ Prapaipit Suwitchayanon, $, 1,3$ Arihiro Iwasaki, ${ }^{2}$ \\ Kiyotake Suenaga ${ }^{2}$ and Hisashi Kato-Noguchi ${ }^{1,3}$ \\ ${ }^{1}$ Department of Applied Biological Science, Faculty of Agriculture, Kagawa University, \\ Miki, Kagawa 761-0795, Japan \\ ${ }^{2}$ Department of Chemistry, Faculty of Science and Technology, Keio University, \\ Yokohama 223-8522, Japan \\ ${ }^{3}$ The United Graduate School of Agriculture Sciences, Ehime University, 3-5-7 Tarumi, Matsuyama, \\ Ehime 790-8566, Japan
}

(Received: March 14, 2018; accepted: May 24, 2018)

\begin{abstract}
Heliotropium indicum L. belongs to the family Boraginaceae. The plant has been used as a folk medicine because it contains substances of various biological activities. It is also identified as a common weed which grows wildly in crop fields in tropical and subtropical regions of the world. However, there is little information on the allelopathic effect in this plant. Therefore, this study was undertaken to investigate the growth inhibitory effect and to identify the growth inhibitory substances in $H$. indicum. An aqueous methanol extract of $H$. indicum inhibited shoot and root growth of barnyard grass, foxtail fescue, timothy, cress, lettuce and rapeseed at concentrations higher than $10 \mathrm{mg}$ dry weight equivalent extract $/ \mathrm{mL}$. The concentrations required for $50 \%$ growth inhibition $\left(I_{50}\right)$ of those test plants ranged from 3-282 mg dry weight equivalent extract $/ \mathrm{mL}$. The extract was then separated using a sequence of chromatographic fractionations and a growth inhibitory substance was isolated and identified by spectral analysis as methyl caffeate. Methyl caffeate inhibited the growth of lettuce and foxtail fescue at concentrations higher than $1.0 \mathrm{mM}$. The results suggest that methyl caffeate may contribute to the growth inhibitory effect of $H$. indicum and may play an important role in the allelopathic effect of $H$. indicum.
\end{abstract}

Keywords: Growth inhibitory effect - Heliotropium indicum - aqueous methanol extract - methyl caffeate - growth inhibitory substance

\section{INTRODUCTION}

Heliotropium belongs to the family Boraginaceae that consists of about 250 species of annual and perennial plants. Heliotropium indicum has been previously reported to have been used in folklore medicine for wound healing, fever, insect bites, abdominal pain and malaria treatments because it possesses anti-inflammatory, antimicrobial, antitumor- and cardiotonic activities [1, 14, 18, 25]. However, this plant is also classified as a weed in rice and corn fields and roadsides $[12,30]$. Since the plant is distributed throughout tropical and subtropical regions in the world [10], it could adapt itself to survive in drought and wet areas and efficiently compete with crops for

\footnotetext{
*Corresponding author; e-mail address: chaipon061@gmail.com
} 
moisture and nutrients [12]. Thus, we were interested in studying allelopathic effects of this plant.

The allelopathic effect of several weed species have been studied and reported to contain allelopathic substances. For example, the methanol extracts of twenty-two weed species inhibited the germination of Abutilon theophrastii, Amaranthus retroflexus, Avena sterilis, Salvia officinalis, Laurus nobilus and Artemisia vulgaris [17]. Ali et al. [4] found ten allelochemicals in the methanol extract of shoots, roots and seeds of Cephalaria syriaca, which is an endemic weed. Plants in the genus Heliotropium have also been reported to have allelopathic effects. Abdulghader et al. [2] stated that the aqueous extract of leaves of $H$. europaeum inhibited the germination of dodder seeds and radish seeds. In addition, ethanol extract of the aerial part of H. indicum has also been reported to decrease the germination and growth of lettuce and black gram [9]. However, there have been no reports about the isolation and identification of the growth inhibitory substances in $H$. indicum. Therefore, the present study was conducted to evaluate for the allelopathic activity and to isolate the growth inhibitory substances in $H$. indicum.

\section{MATERIALS AND METHODS}

\section{Plant materials}

Whole plants (roots, stems, leaves and flowers) of Heliotropium indicum (L.) were collected from Chiang Rai, Thailand. The plants were washed several times with tap water and dried in the shade. The dried plants were ground into powder by a grinding machine. The plant powder was then packed in vacuum-sealed plastic bags and kept at $4{ }^{\circ} \mathrm{C}$. Monocotyledonous plants, barnyard grass (Echinochloa crus-galli (L.) P. Beauv.), foxtail fescue (Vulpia myuros (L.) C.C.Gmel.) and timothy (Phleum pretense L.); and dicotyledonous plants, cress (Lepidium sativum L.), lettuce (Lactuca sativa L.) and rapeseed (Brassica napus L.) were selected to determine the growth inhibitory effect of the extracts.

\section{Extraction and bioassay}

The powder $(500 \mathrm{~g})$ of $H$. indicum was extracted with $2.5 \mathrm{~L}$ of $70 \%(\mathrm{v} / \mathrm{v})$ aqueous methanol for $48 \mathrm{~h}$ and filtrated through a filter paper (No. 2; Toyo, Tokyo, Japan). The residue was extracted again with methanol for $24 \mathrm{~h}$ and filtrated. Both filtrates were combined and concentrated with a rotary evaporator at $40{ }^{\circ} \mathrm{C}$. The crude extract was dissolved in methanol to obtain the final concentrations 1, 3, 10, 30, 100 and $300 \mathrm{mg}$ dry weight equivalent extract $/ \mathrm{mL}$. Each concentration of the extract was added to a sheet of filter paper (No. 2) in each a $28 \mathrm{~mm}$ Petri dish and the solvent was then evaporated until it dried in a draft chamber. Then, the filter paper was moistened with $0.6 \mathrm{~mL}$ of $0.05 \%(\mathrm{v} / \mathrm{v})$ aqueous solution of Tween 20 (Polyoxy- 
ethylene sorbitan monolaurate, Nakalai Tesque, Inc, Kyoto, Japan). Ten germinated seeds of barnyard grass, foxtail fescue and timothy were placed separately on the filter paper in Petri dishes after pre-germination for $72 \mathrm{~h}, 48 \mathrm{~h}$ and $60 \mathrm{~h}$ at $25^{\circ} \mathrm{C}$ in darkness, respectively. Ten seeds of cress, lettuce and rapeseed were also placed separately. The germinated seeds and seeds with only the aqueous solution of Tween 20 were used as control treatments. Shoot and root length of the test plants were measured at $48 \mathrm{~h}$ after incubation at $25{ }^{\circ} \mathrm{C}$ in darkness. The inhibition percentage was calculated using the following formula: Inhibition $(\%)=[1-($ length of treatment/length of control) $] \times 100$. The experiment was performed on thirty seedlings for each treatment. Concentrations required for $50 \%$ growth inhibition $\left(I_{50}\right.$ values $)$ on test plants were calculated by the regression equation of the concentrationresponse curves.

\section{Isolation and purification of active substances}

The aqueous methanol extract of $H$. indicum was concentrated using a rotary evaporator at $40{ }^{\circ} \mathrm{C}$ to produce an aqueous residue. The aqueous residue was adjusted to $\mathrm{pH} 7.0$ with $1 \mathrm{~N} \mathrm{NaOH}$ and partitioned 5 times against $100 \mathrm{~mL}$ of ethyl acetate. The ethyl acetate fraction was concentrated to dryness and separated using a column of silica gel (60 g, silica gel 60, spherical, 70-230 mesh: Nacalai Tesque, Kyoto, Japan), eluted with $20,30,40,50,60,70,80,90 \%$ of ethyl acetate in $n$-hexane (v/v; $150 \mathrm{~mL}$ per step) and methanol $(300 \mathrm{~mL})$. The active fractions were found in fractions obtained by elution with 60 (F5) and 70\% (F6) of ethyl acetate in $n$-hexane. The two active fractions were combined and evaporated to dryness. The residue was dissolved in $20 \%$ aqueous methanol and loaded onto a Sephadex LH-20 column (100 g, GE Healthcare Bio-Science AB, Sweden), eluted with 20,40,60, 80\% of aqueous methanol $(\mathrm{v} / \mathrm{v} ; 150 \mathrm{~mL}$ per step) and methanol $(300 \mathrm{~mL})$. The active fraction was found in fraction obtained by elution with $80 \%$ of aqueous methanol and concentrated until dry. The residue was dissolved in $20 \%$ (v/v) aqueous methanol and loaded into reverse-phase $\mathrm{C}_{18}$ cartridge $(1000 \mathrm{mg} / 6 \mathrm{~mL}, 6 \mathrm{~nm}$, YMC Dispo SPE, YMC Ltd., Kyoto, Japan), eluated with 20, 30, 40, 50, 60, 70, 80, 90\% of aqueous methanol (v/v; $15 \mathrm{~mL}$ per step) and methanol $(30 \mathrm{~mL})$. The active fraction was found in fraction obtained by elution with $30 \%$ aqueous methanol and concentrated to dryness. The residue of active fraction was purified by reverse-phase HPLC $(500 \times 10$ $\mathrm{mm}$ I.D, ODS AQ-325; YMC Ltd, Kyoto, Japan), eluated with $35 \%(\mathrm{v} / \mathrm{v})$ aqueous methanol at a flow rate of $1.5 \mathrm{~mL} / \mathrm{min}$, and detected at $220 \mathrm{~nm}$. The growth inhibitory effect in each isolation and purification step was determined using a cress bioassay. An active substance was identified by high-resolution electrospray ionization mass spectrometry (HR-ESI-MS), ${ }^{1} \mathrm{H}$ NMR (400 MHz, $\left.\mathrm{CD}_{3} \mathrm{OD}\right)$ and ${ }^{13} \mathrm{C}$ NMR (100 $\left.\mathrm{MHz}, \mathrm{CD}_{3} \mathrm{OD}\right)$. 


\section{Bioassay of methyl caffeate}

The growth inhibitory effect of methyl caffeate was determined using lettuce and foxtail fescue bioassay. The compound was dissolved in $1 \mathrm{~mL}$ of methanol to prepare final concentrations of $0.1,0.3,1,3$ and $10 \mathrm{mM}$. Each concentration was dropped into a sheet of filter paper (No. 2) in each a $28 \mathrm{~mm}$ Petri dish, as described above. Shoot and root length of test plants were measured at $48 \mathrm{~h}$ after incubation at $25{ }^{\circ} \mathrm{C}$ in darkness. The inhibition percentage was calculated using formula as described above. The $I_{50}$ values on two test plants were calculated by the regression equation of the concentration-response curves.

\section{Statistical analysis}

The bioassay experiment was completed with thirty seedlings for each treatment and repeated twice. Treatments were prepared in a completely randomized design. Data were analyzed by SPSS version 22.0 using one-way ANOVA.

\section{RESULTS}

\section{The inhibitory effect of $\mathrm{H}$. indicum extract on shoot growth}

The extract of $H$. indicum inhibited shoot growth of test plants at concentrations greater than $10 \mathrm{mg}$ dry weight equivalent extract $/ \mathrm{mL}$ (Table 1). The extracts at $30 \mathrm{mg}$ dry weight equivalent extract $/ \mathrm{mL}$ inhibited shoot growth of cress, lettuce and rapeseed seedlings by $95.5,93.0$ and $78.3 \%$, respectively. At $300 \mathrm{mg}$ dry weight equivalent extract/mL, the extract completely inhibited cress, lettuce and rapeseed seedlings, and inhibited foxtail fescue and timothy seedlings by $99.0 \%$ and $91.0 \%$, respectively. The $I_{50}$ values of shoot growth of all test plants were in the range of 7-282 mg dry weight equivalent extract $/ \mathrm{mL}$. On the basis of $I_{50}$ values, cress shoots were the most sensitive to the extract followed by lettuce and rapeseed shoots. While, barnyard grass shoots were less sensitive than foxtail fescue, timothy, rapeseed, lettuce and cress shoot.

\section{The inhibitory effect of $\mathrm{H}$. indicum extract on root growth}

The extract of $H$. indicum inhibited root growth of test plant at concentrations greater than $10 \mathrm{mg}$ dry weight equivalent extract $/ \mathrm{mL}$. The extracts at $30 \mathrm{mg}$ dry weight equivalent extract $/ \mathrm{mL}$ completely inhibited the root growth of timothy seedlings and inhibited lettuce, cress, foxtail fescue, rapeseed and barnyard grass seedlings by 95.6 , $93.5,92.0,88.1$ and $58.6 \%$, respectively. At $300 \mathrm{mg}$ dry weight equivalent extract/ $\mathrm{mL}$, the extract completely inhibited root growth of all test plants (Table 2). The $I_{50}$ 

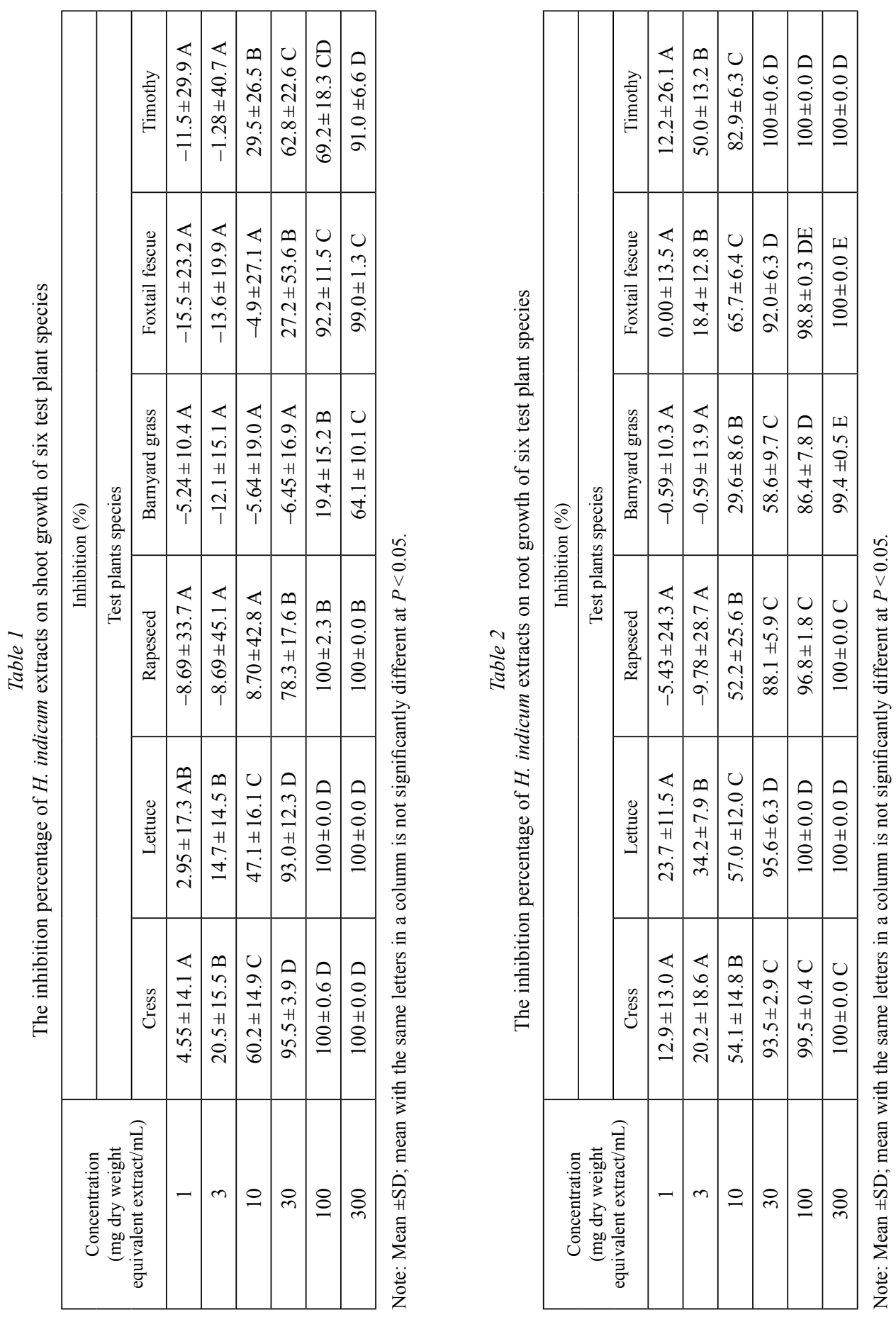

Acta Biologica Hungarica 69, 2018 
Table 3

$I_{50}$ values of the $H$. indicum extracts on shoot and root growth of six test plant species

\begin{tabular}{|l|c|c|}
\hline \multirow{2}{*}{\multicolumn{1}{c|}{ Test plant species }} & \multicolumn{2}{|c|}{$I_{50}(\mathrm{mg}$ dry weight equivalent extract $/ \mathrm{mL})$} \\
\cline { 2 - 3 } & Shoot & Root \\
\hline Cress & 7 & 7 \\
\hline Lettuce & 9 & 5 \\
\hline Rapeseed & 20 & 12 \\
\hline Barnyard grass & 282 & 23 \\
\hline Foxtail fescue & 48 & 7 \\
\hline Timothy & 27 & 3 \\
\hline
\end{tabular}

Note: The values were determined by a logistic regression analysis after bioassays.

values of root growth of all test plants were in the range of 3-23 mg dry weight equivalent extract $/ \mathrm{mL}$. Timothy roots were the most sensitive to the extract followed by lettuce and foxtail fescue roots (Table 3).

\section{Isolation and identification of a growth inhibitory substance}

The residue of ethyl acetate fraction was loaded into silica gel column and the fractions with high inhibitory activities were found in F5 and F6 (Fig. 1). At the concentration $0.6 \mathrm{~g}$ dry weight equivalent extract $/ \mathrm{mL}$, F5 and F6 completely inhibited $(100 \%)$ shoot growth of cress and inhibited root growth by 94.5 and $96.2 \%$, respec-

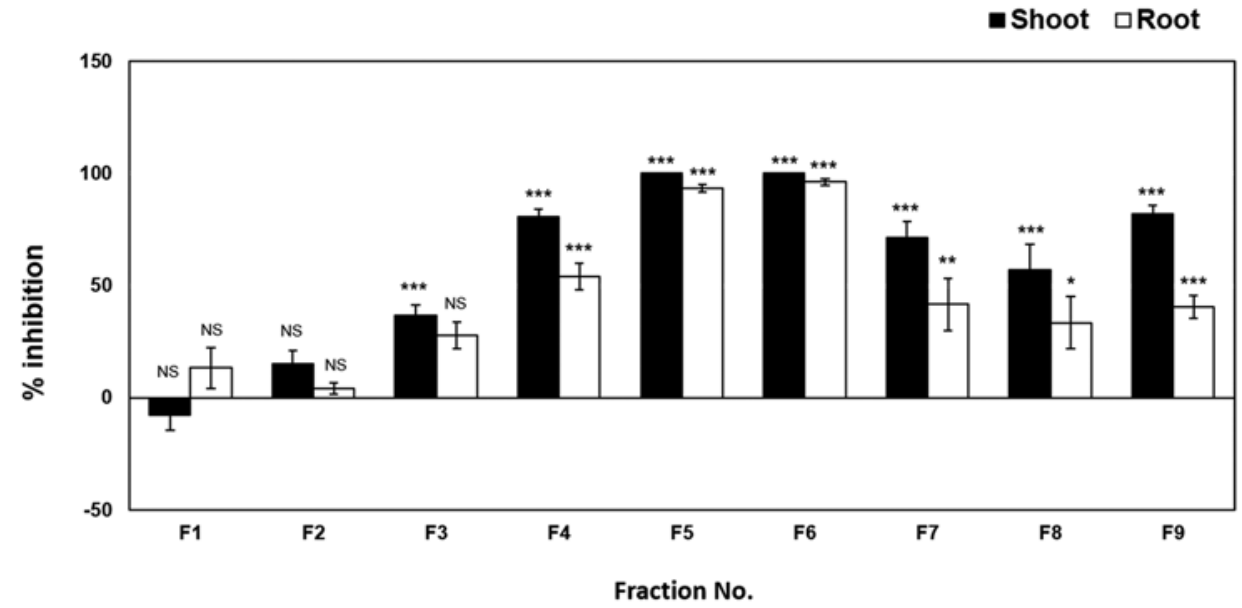

Fig. 1. Inhibitory effects of fractions obtained by the column of silica gel on shoot and root growth of cress seedlings at the concentration $0.6 \mathrm{~g}$ dry weight equivalent extract $/ \mathrm{mL}$. Values represent means $\pm \mathrm{SE}$ from two independent experiments with 10 seedlings for each treatment. Asterisks indicate significant difference between control and treatments: $* P<0.05$, $* * P<0.01$ and $* * * P<0.001$ 


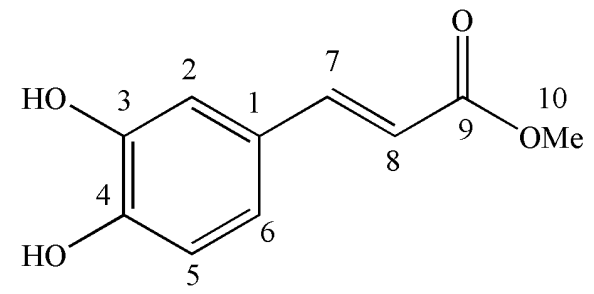

Fig. 2. The chemical structure of methyl caffeate

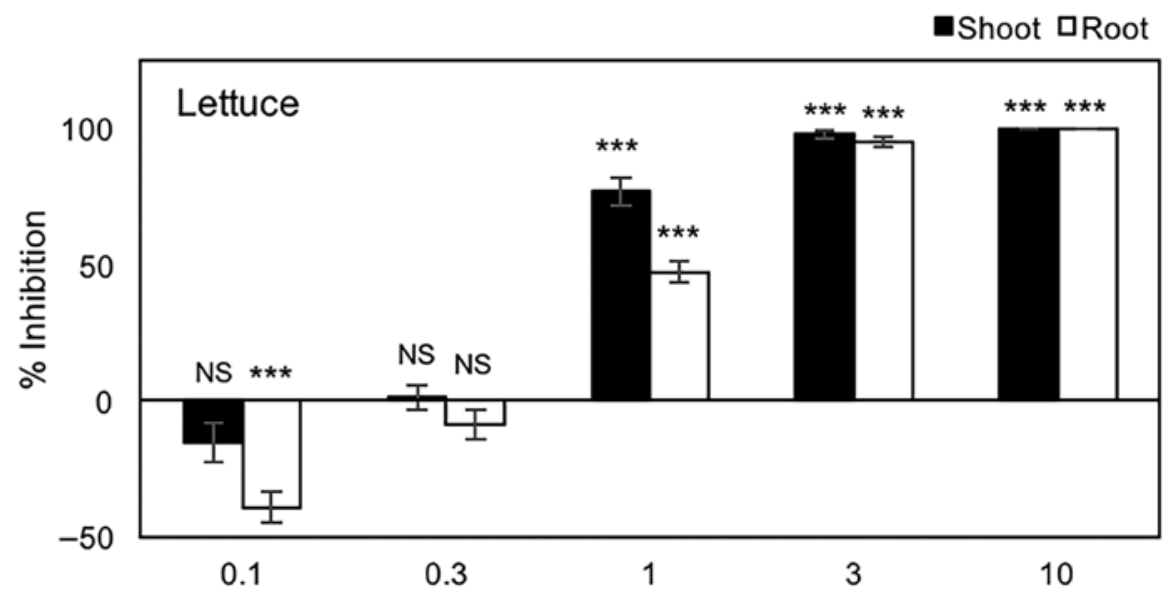

- Shoot $\square$ Root

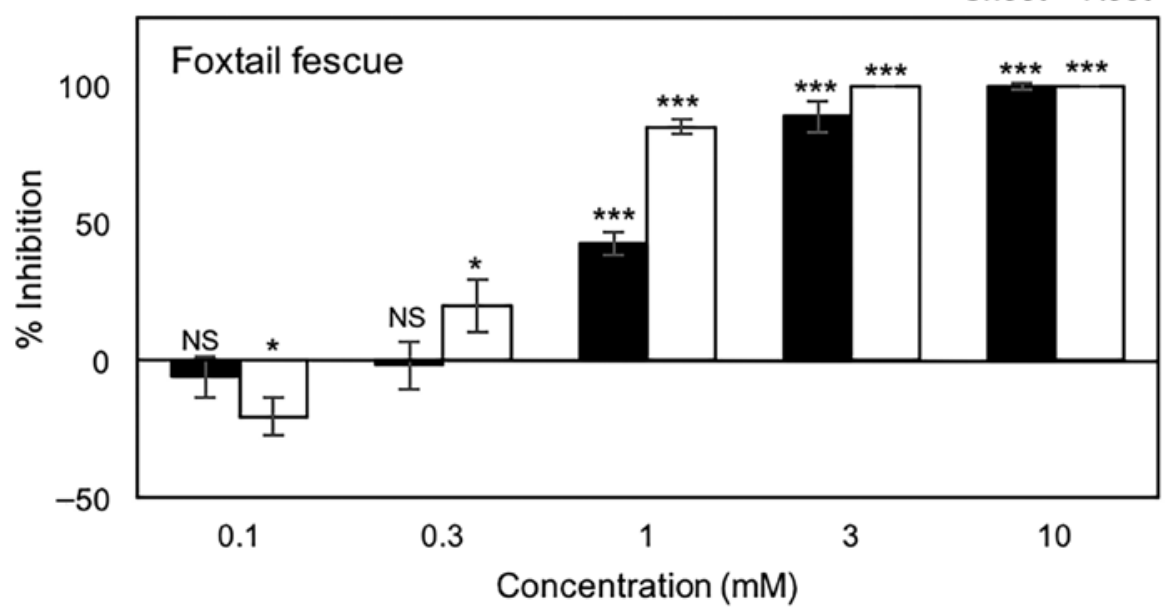

Fig. 3. Effects of methyl caffeate on shoot and root growth of lettuce and foxtail fescue. Values represent means \pm SE from two independent experiments with 10 seedlings for each treatment. Asterisks indicate significant difference between control and treatments: $* P<0.05 ; * * * P<0.001$; NS: non-significant 
tively. The two active fractions were combined and further separated by chromatographic fractionations. An active substance was isolated and identified by spectral analysis. The molecular formula of an active substance was determined as $\mathrm{C}_{10} \mathrm{H}_{10} \mathrm{O}_{4}$ by HR-ESI-MS $m / z 192.9761\left([\mathrm{M}-\mathrm{H}]^{-}\right.$) (calcd for $\left.\mathrm{C}_{10} \mathrm{H}_{9} \mathrm{O}_{4} 193.0501, \Delta=-383 \mathrm{ppm}\right)$; ${ }^{1} \mathrm{H}$ NMR $\left(400 \mathrm{MHz}, \mathrm{CD}_{3} \mathrm{OD}\right) \delta_{\mathrm{H}} 7.54(\mathrm{~d}, J=16.2 \mathrm{~Hz}, 1 \mathrm{H}, \mathrm{H}-7), 7.03(\mathrm{~d}, J=2.1 \mathrm{~Hz}$, $1 \mathrm{H}, \mathrm{H}-2), 6.94$ (dd, $J=8.4,2.1 \mathrm{~Hz}, 1 \mathrm{H}, \mathrm{H}-6), 6.77$ (d, $J=8.4 \mathrm{~Hz}, 1 \mathrm{H}, \mathrm{H}-5), 6.26$ $(\mathrm{d}, J=16.2 \mathrm{~Hz}, 1 \mathrm{H}, \mathrm{H}-8), 3.76(\mathrm{~s}, 3 \mathrm{H}, \mathrm{H}-10) ;{ }^{13} \mathrm{C}$ NMR $\left(100 \mathrm{MHz},\left(\mathrm{CD}_{3} \mathrm{OD}\right) \delta_{\mathrm{C}}\right.$ 169.8 (C-9), 149.6 (C-4), 147.0 (C-3), 146.8 (C-7), 127.6 (C-1), 122.9 (C-6), 116.5 (C-5), 115.1 (C-8), $114.8(\mathrm{C}-2), 52.0(\mathrm{C}-10)$. The substance was characterized as methyl caffeate (Fig. 2) by comparison of the spectroscopic data with previously reported in the literature $[23,32]$.

\section{Growth inhibitory effect of methyl caffeate}

Methyl caffeate inhibited shoot and root growth of lettuce and foxtail fescue at concentrations greater than $1 \mathrm{mM}$ (Fig. 3). Methyl caffeate at $10 \mathrm{mM}$ completely inhibited $(100 \%)$ shoot growth of the test plants. The inhibitory effects depended on test plant species and methyl caffeate concentration. The $I_{50}$ values of methyl caffeate on lettuce shoots and roots were 0.7 and $1.0 \mathrm{mM}$, respectively, and those on foxtail fescue shoots and roots were 1.3 and $0.5 \mathrm{mM}$, respectively.

\section{DISCUSSION}

The aqueous methanol extracts of $H$. indicum exerted inhibitory effects on seedling growth of six test plant species. The variation of growth inhibition depended on the test plant species and the extract concentrations. The results are in agreement with previous studies demonstrations also that the inhibitory effects of the extract on seedling growth depended on the plant species and the concentrations applied [16, 27]. The plant extracts showed higher inhibition on roots than shoots of all test plant species. The reduction of root growth might be due to the direct contact between roots and the putative allelochemicals which affect the morphological and physiological process such as cell division, cell elongation, membrane permeability and ion uptake [26]. Afef et al. [3] reported that allelopathic effect of aqueous and methanol extract of Capparis spinose leaves and Cleome arabica siliguea showed a cytotoxic effect on the root tip of Lactuca sativa including cell membrane damage and reduction of mitotic index. Moreover, Lara-Nuñez et al. [19] and Ma et al. [22] reported that the inhibition of root growth and root cell damage were found in a state of allelopathic stress. Regarding $I_{50}$ values, our results show that dicotyledonous plants are more sensitive to the extracts than monocotyledonous plants. Similar results were also found by Ma et al. [21], who reported that the germination and growth of rapeseed and sesame (dicotyledonous plants) were more sensitive to an aqueous extract of Stellala chamaejasma than wheat and maize (monocotyledonous plants). These result 
suggests that $H$. indicum may possess an allelopathic effect and contain growth inhibitory substances.

The investigation of the inhibitory effect of $H$. indicum extract led to the isolation and identification of an active substance. A growth inhibitory substance was characterized as methyl caffeate, which is the derivative of caffeic acid, and is oxidized to quinone $[5,20]$. In the present study, methyl caffeate had a growth inhibitory effect on lettuce and foxtail fescue seedlings. The growth of the two test plant seedlings was reduced by increasing methyl caffeate concentrations. Considering the quinones, some compounds that have allelopathic property have been reported to possess a quinoidal structure $[11,28]$. Moreover, Inbaraj and Chignell [15] reported that the mechanism of quinones (juglone and plumbagin) affected the redox cycling, increasing $\mathrm{H}_{2} \mathrm{O}_{2}$ generation and the oxidation of glutathione (GSH), which is a reason for its toxicity. The growth inhibitory effect of methyl caffeate may be a result of its quinone derivatives. Methyl caffeate has been isolated from several plants, such as Magnolia obavata [24], Polygonum amplexicaule [31] and Solanum torvum [7]. This compound has been reported to possess antihyperglycemic [13], antimicrobial [6], anticancer [8] and antioxidant activities [29]. Although methyl caffeate has been isolated from several plants, its presence has never been reported in $H$. indicum. Therefore, this may be the first report on methyl caffeate as a growth inhibitory substance in H. indicum.

\section{ACKNOWLEDGMENT}

The authors acknowledge the support of the Government of Japan, providing a scholarship to Sirinapa C

\section{REFERENCES}

1. Abubakar, M. S., Musa, A. M., Ahmed, A., Hussaini, I. M. (2007) The perception and practice of traditional medicine in the treatment of cancers and inflammations by the Hausa and Fulani tribes of Northern Nigeria. J. Ethnopharmacol. 111, 625-629.

2. Abdulghader, K., Majid, N., Nabat, N. (2008) Chemical stress induced by Heliotrope (Heliotropium europaeum L.) allelochemicals and increased activity of antioxidant enzymes. Pak. J. Biol. Sci. 11, 915-919.

3. Afef, L., Omezzine, F., Haouala, R. (2014) The impact of tunisian capparidaceae species on cytological, physiological and biochemical mechanisms in lettuce. S. Afr. J. Bot. 93, 222-230.

4. Ali, K. A., Sakri, F. Q., Li, Q. X. (2012) Isolation and purification of allelochemicals from Cephalaria syriaca plant. Int. J. Bio. sci. 2, 90-103.

5. Arakawa, R., Yamaguchi, M. (2004) Product analysis of caffeic acid oxidation by on-line electrochemistry/electrospray ionization mass spectrometry. J. Am. Soc. Mass. Spectrom. 15, 12281236.

6. Balachadran, C., Veeramuthu, D., Naif, A. A., Balakrishna, K., Nitin, P. K., Vikrant, S. R., Inshad, A. K., Savarimuthu, I. (2012) Antimicrobial and antimycrobacterial activities of methyl caffeate isolated from Solanum torvum Swartz. fruit. Indian J. Microbiol. 4, 676-681.

7. Balachadran, C., Emi, N., Arun, Y., Yamamoto, Y., Ahilan, B., Sangeetha, B., Duraipandiyan, V., Inaguma, Y., Okamoto, A., Ignacimuthu, S., Al-Dhadi, N. A., Perumal, P. T. (2015) In vitro anticancer activity of methyl caffeate isolated from Solanum torvum Swartz. fruit. Chem. Biol. Interact. 242, $81-90$. 
8. Bailly, F., Robert, A. T., Olympe, T., Nathalie, J., Hubert, H., Philippe, C. (2013) Antiproliferative and apoptotic effects of the oxidative dimerization product of methyl caffeate on human breast cancer cells. Bioorg. Med. Chem. Lett. 23, 574-578.

9. Das, S., Coku, A. (2014) Allelopathic and antimicrobial evaluation of two Indian weeds Heliotropium indicum L. and Synedrella nodiflora L. Gaertn with phytochemical studies. Am. J. PharmTech R. 4, 367-377.

10. Dash, G. K., Abdulla, M. S. (2013) A review on Heliotropium indicum L. (Boraginaceae). Int. J Pharm. Sci. Res. 4.4, 1253-1258.

11. Dayan, F. E., Howell, J., Weidenhamer, J. D. (2009) Dynamic root exudation of sorgoleon and its in planta mechanism of action. J. Exp. Bot. 60.7, 2107-2117.

12. Galinato, M. I., Moody, K., Piggin, C. M. (1999) Upland rice weeds of South and Southeast Asia. Philippines International Rice Research Institute, Makati, Philippines.

13. Gandhi, G. R., Savarimuthu, I., Michael, G. P., Ponnusamy, S. (2011) Antihyperglycemic activity and antidiabetic effect of methyl caffeate isolated from Solanum torvum Swartz. fruit in streptozotocin induced diabetic rats. Eur. J. Pharmacol. 670, 623-631.

14. Ghori, K. M., Ghaffari, M. A., Hussain, S. N., Manzoor, M., Aziz, M., Sarwer, W. (2016) Ethnopharmacological, phytochemical and pharmacognostic potential of genus Heliotropium L. Turk. J. Pharm. Sci. 13, 259-280.

15. Inbaraj, J. J., Chignell, C. F. (2004) Cytotoxic action of juglone and plumbagin: a mechanistic study using HaCaT keratinocytes. Chem. Res. Toxicol. 17, 55-62.

16. Islam, M. S., Kato-Noguchi, H. (2016) Phytotoxicity assessment of Cyperus difformis (L.) towards a sustainable weed management option. J. Anim. Plant Sci. 26, 1765-1771.

17. Kadioglu, I., Yanar, Y. (2004) Allelopathic effects of plant extracts against seed germination of some weeds. Asian J. Plant Sci. 3, 472-475.

18. Kugelman, M., Liu, W. C., Axelrod, M., McBride, T. J., Rao, K. V. (1976) Indicine-N-oxide: the antitumor principle of Heliotropium indicum. Lloydia. 39, 125-128.

19. Lara-Nunez, A., Romero-Romero, T., Ventura, J. L., Blancas, V., Anaya, A. L., Cruz-Ortega, R. (2006) Allelochemical stress caused inhibition of growth and oxidative damages in Lycopersicon esculentum Mill. Plant, Cell and Environment 29, 2009-2016.

20. Lee, S. P., Jun, G., Yoon, E., Park, S., Yang, C. (2001) Inhibitory effect of methyl caffeate on Fos-Jun-DNA complex formation and suppression of cancer cell growth. Bull. Korean Chem. Soc., 22.10, 1131-1135.

21. Ma, L., Hongli, W., Ru, B., Li, Z., Xiaohong, Y., Dabin, H. (2011) Phytotoxic effects of Stellera chamaejasme L. root extract. Afr. J. Agric. Res. 6, 1170-1176.

22. Ma, D. W., Wang, Y. N., Wang, Y., Zhang, H., Liao, Y., He, H. (2015) Advance in allelochemical stress induced damage to plant cell. Acta Ecol. Sin. 35, 1640-1645.

23. Prevost, M. S., Delarue-Cochin, S., Marteaux, J., Colas, C., Van, R. C., Blondel, A., Malliavin, T., Corringer, P. J., Joseph, D. (2013) Identification of cinnamic acid derivatives as novel antagonist of the prokaryotic proton-gated ion channel GLIC. J. Med. Chem. 56, 4619-4630.

24. Pyo, M. K., Yong, Y. L., Hye, Y. C. (2002) Anti-platelet effect of the constituents isolated from the barks and fruits of Magnolia obovate. Arch. Pharm. Res. 25, 325-328.

25. Reddy, J. S, Rao, P. R., Reddy, M. S. (2002) Wound healing effects of Heliotropium indicum, Plumbago zeylanicum and Acalypha indica in rats. J. Ethnopharmacol. 79, 249-251.

26. Rice, E. L. (1984) Allelopathy, 2nd Ed. Academic Press, Orlando.

27. Suleiman, M. H. A., Banaga, F. A. (2016) Evaluation of allelopathic action of Adansonia digitate L. root extract on the germination and growth of lettuce, hibiscus and sorgum. Int. J. Pharm. Sci. Rev. Res. 37, 137-142.

28. Vilhena, K. S., Guilhon, G. M., Zoghbi, M. D., Santos, L. S., Souza Filho, A. P. (2014) Chemical investigation of Cyprus distans L. and inhibitory activity of scabequinone in seed germination and seedling growth bioassays. Nat. Prod. Res. 28.23, 2128-2133. 
29. Wang, J., Jia, G., Junnan, Z., Jie, P., Tianxing, L., Zhihong, X. (2015) Isolation, identification and antioxidant activity of bound phenolic compounds present in rice bran. Food Chem. 171, 40-49.

30. Waterhouse, D. F. (1993) The major arthropod pests and weeds of agriculture in southeast Asia: distribution, importance and origin. Brown Prior Anderson, Victoria, Australia.

31. Xiang, M., Hanwen, S., Jinyue, H., Yunjin, Y. (2011) Isolation, identification and determination of methyl caffeate, ethyl caffeate and other phenolic compounds from Polygonum amplexicaule var. sinense. J. Med. Plants Res. 5, 1685-1691.

32. Zhu, Y., Zhang, L. X., Zhao, Y., Huang, G. D. (2010) Unusual susquiterpene lactones with a new carbon skeleton and new acetylenes from Ajania przewalskii. Food Chem. 118, 228-238. 